\title{
IDŐJÁRÁS
}

Quarterly Journal of the Hungarian Meteorological Service

Vol. 124, No. 2, April-June, 2020, pp. 191-207

\section{Modeling the urban climate of Budapest using the SURFEX land surface model driven by the ALADIN-Climate regional climate model results}

\author{
Gabriella Zsebeházi * and Gabriella Szépszó \\ Hungarian Meteorological Service \\ P.O. Box 38, H-1525 Budapest, Hungary \\ * Corresponding author E-mail: zsebehazi.g@met.hu
}

(Manuscript received in final form March 11, 2020)

\begin{abstract}
Urbanized areas modify the local climate due to the physical properties and morphology of surface objects. The urban impacts on local scale interact with the regional climate resulting in an amplification of certain climate aspects in the cities (e.g., higher maximum air temperature), which may be further enhanced with climate change. Regional climate models provide adequate tool for assessing the regional characteristics of global changes, however, they are incapable for describing the local impacts, e.g., in cities, due to their relatively low resolution (usually 10-25 km horizontally) and due to the lack of detailed description of relevant physical processes. To investigate the future climate change in cities, surface models provide a scientifically sound and cutting-edge solution for the previous problem. In this study, the behavior of SURFEX externalized land surface model including the TEB urban canopy scheme and coupled to the ALADIN-Climate regional climate model in offline mode is investigated. A 10-year-long simulation for 2001-2010 was achieved on $1 \mathrm{~km}$ resolution for Budapest. The main goals of our investigation are i) to assess how the biases of the regional climate model inherited and modified by SURFEX, ii) what is the added value of SURFEX to ALADIN-Climate, and iii) what are the capabilities of SURFEX in terms of describing urban and suburban seasonal temperature cycle and daily urban heat island (UHI) evolution in Budapest. Quantified validation is conducted using the measurements of two stations located in the city center and in the suburban area. It was found that SURFEX overestimates the $2 \mathrm{~m}$ temperature in both locations throughout the year, in spite of the too cold ALADIN forcings. The strength of nocturnal UHI is overestimated from autumn till spring, while it is slightly too weak in summer. Moreover, the evolution and collapse of daily UHI is imperfectly simulated, namely some delay and slower daily dynamics occur, which might be caused by the method applied for deriving the atmospheric forcings.
\end{abstract}

Key-words: urban climate change, urban heat island, land surface modelling, SURFEX, TEB, ALADIN-Climate, validation 


\section{Introduction}

More than half of the world's population lives in cities nowadays, and this rate is projected to increase to $66 \%$ by 2050 (UN, 2014). The growing number of cities' inhabitants has been detected also in Hungary in the past decades, which currently counts $70 \%$ of total population $(K S H, 2013)$. The air of cities is warmer, drier, and more polluted than of natural areas due to the specific surface characteristics (i.e., impervious surfaces, narrow streets, high buildings, large heat capacity of buildings) and anthropogenic activity (e.g., internal heating and transportation; Oke, 1987). All these cause that cities are especially exposed to the impacts of climate change.

To tackle these challenges, proper adaptation and mitigation strategies - supported by targeted vulnerability studies - are needed. Different methodologies with different complexity exist to quantitatively estimate the impact of climate change in cities. Wilby (2003) developed a multivariate statistical model, in which a relationship was set up between the atmospheric variables (e.g., near surface wind speed, relative humidity, vorticity) and the nocturnal urban heat island (UHI) for London. They used the statistical model to project the future changes. Although this method does not require large computing capacity, its greatest drawback is that it lacks the physical relationship between the atmospheric and land surface processes, which might alter the statistical relations as time goes by. Large-eddy simulation (LES) models take place on the other end of complexity, they partially resolve turbulence and are able to investigate atmospheric processes in cities on meterscale with an appropriate urban surface module, such as the PALM-USM (Parallelized Large-Eddy Simulation Model - Urban Surface Model) model (Resler et al., 2017). Their very high resolution and elaboration require extremely large computation capacity; therefore, they are used for short periods, but it is almost impossible to apply them for a whole city for several decades in transient mode. Urban canopy surface balance models (Masson, 2006) simulate surface energy balance components and energy transfer in the Prandtl-layer on the neighborhood scale, i.e., individual building characteristics (e.g., geometry, material) are averaged, streets are considered as a unit. These simplifications enable to apply them on long timescale (decades) with $\mathrm{km}$-scale resolution. For example, Hamdi et al. (2015) examined the urban climate change in Brussels and Paris in the mid-21st century using SURFEX (Surface Externalisé) driven by $^{1}$ the $\mathrm{ALARO}^{2}$ model. McCarthy et al. (2010) simulated the global response of cities to doubling $\mathrm{CO}_{2}$ by inline coupling the MOSES (Met Office Surface Exchange Scheme) land surface model to the HadAM3 (Hadley Centre

\footnotetext{
${ }^{1}$ SURFEX can be coupled to its driving model in two ways. Offline coupling refers to standalone mode, when SURFEX has no feedback to its driving model. Inline coupling means two-way coupling, in which case SURFEX outputs influence the driving model as well.

${ }^{2}$ ALARO stands for ALADIN-AROME, and it is a development of ALADIN mesoscale model with a physics parameterization package designed specifically for convection-permitting resolutions.
} 
Atmospheric Model version 3) global climate model. Lemonsu et al. (2015) assessed the impact of different urban expansion scenarios under heat waves in Paris using the TEB (Town Energy Balance) urban scheme driven by the MesoNH (Mesoscale Non-hydrostatic Model) numerical model.

At the Hungarian Meteorological Service, the SURFEX (Le Moigne, 2009) surface model coupled to the ALADIN-Climate (climate version of the $\mathrm{ALADIN}^{3}$ numerical weather prediction model; hereinafter ALADIN) is applied for urban climate investigations. A detailed validation procedure has been started, in order to familiarize the model behavior and reveal its capabilities from the aspect of our needs. Vértesi (2011) analyzed $2 \mathrm{~m}$ temperature and $10 \mathrm{~m}$ horizontal wind field of a 10-year (1961-1970) SURFEX simulation over Budapest. The study compared grid point model data against urban and suburban station measurements. It was concluded that SURFEX adds extra heat to the ALADIN fields principally over the city, catching the urban heat island phenomenon (especially in spring and autumn). On the other hand, the study revealed that the simulated diurnal summer temperature in the urban point is colder than in the suburban point. Krüzselyi et al. (2016) performed similar investigation for the period of 1991-2000 and compared the results to those of 1961-1970. They examined i) whether the temperature biases in the two gridpoints change with time, and ii) whether using the land cover dataset based on recent surface information in SURFEX simulations explains the relatively warmer temperature of the suburb of Budapest in the 60s (note that these areas were greener at that time). They found that the investigated gridcells are characterized with the same type (temperate suburban) in the land cover dataset, which explains the lack of urban heat island emergence in SURFEX, contrary to measurements. Therefore, other grid point - which is described as urban point in the database - has to be selected to study the UHI. It implies also to choose a more recent validation period, since new measurement stations inside the city have been installed only from the 2000s.

In this paper, the applicability of SURFEX land surface model was investigated from the aspect of describing the urban climate of Budapest. Validation results of SURFEX and its driving model, ALADIN are presented for Budapest for the period of 2001-2010. We explore more in detail the impact of ALADIN results on SURFEX daily and sub-daily temperature and UHI results in a newly selected urban gridpoint, where the land cover database performs better. The paper is organized as follows: the overview of the model and experimental design is presented in Section 2, in Section 3, the performance of ALADIN over Budapest is assessed and temperature results of SURFEX and its added value to the regional climate model (RCM) are investigated. Finally, the conclusions of our results and future plans are given in Section 4.

\footnotetext{
${ }^{3}$ ALADIN stands for Air Limitée Adaptation Dynamique Dévéloppement International.
} 


\section{Models and methods}

\subsection{The SURFEX land surface model}

SURFEX simulates energy, momentum, and moisture fluxes between the surface and the surface boundary layer (SBL; lower $10 \%$ of the planetary boundary layer). In order to bridge the gap between the model resolution (typically $1 \mathrm{~km}$ ) and the heterogeneity of land cover, the model applies the tiling method, i.e., a grid cell may be composed of four different surface types (nature, sea, inland water, and town). For each tile, different parameterization scheme computes the relevant fluxes, which are then area weighted aggregated over the grid cell. Advection is not taken into account in SURFEX, meaning there is no interaction between neighboring grid points.

From the aspect of urban climate investigation, in Hungary two surface types, the urban and natural surfaces are in focus. Over urban surfaces the Town Energy Balance (TEB) scheme (Masson, 2000) is applied, which approximates the complex geometry of cities with the canyon concept. It means that streets are represented by roads with homogenous, uniform buildings on their two sides. Real orientation of roads is not taken into account it is integrated over all directions instead. Town characteristics are described by three main parameters: building height, building aspect ratio (rate of building height and roof width), and canyon aspect ratio (rate of building height and canyon width). TEB computes moisture budget for roof and road and energy budget for roof, wall, and road separately. Heat conduction is parameterized with considering several layers in urban surfaces. Heating, traffic, and industrial sourced anthropogenic energy and moisture fluxes are also taken into account.

Physical processes of natural surfaces are computed by the ISBA (Interaction Soil Biosphere Atmosphere) scheme (Noilhan and Mahfouf, 1996), which applies the force-restore method (Noilhan and Planton, 1989) to determine surface temperature and water content evolution. Ground is divided into three layers (Boone et al., 1999) for describing heat and moisture conduction.

Atmospheric forcings for the model are short and longwave downward radiation, temperature, wind speed and wind direction, specific humidity, surface pressure and precipitation which are prescribed on a few tenth of meter above surface. These forcings can be supplied either by measurements or available atmospheric model results.

In the model, surface boundary layer is resolved by the Surface Boundary Layer scheme (Masson and Seity, 2009; Hamdi and Masson, 2008) that introduce several model levels between the surface and the forcing level, and computes temperature, humidity (e.g., on 2-m height), wind speed (e.g., on 10-m height), and turbulent fluxes in prognostic equations. 


\subsection{The ALADIN-Climate model}

Atmospheric forcings for SURFEX were provided by the ALADIN-Climate version 5.2 regional climate model (Colin et al., 2010). ALADIN-Climate was developed at the Météo-France by combining the dynamical core of the ALADIN hydrostatic weather prediction model (Termonia et al., 2018) and the physical parameterization package of the ARPEGE-Climat (climate version of ARPEGE; Action de Recherche Petite Echelle Grande Echelle; Déqué et al., 1994) general circulation model. The land surface model of ALADIN is SURFEX, in which ISBA computes the fluxes over natural tiles, and urban covers are not taken into account.

\subsection{Experimental setup}

In order to investigate how the model describes the urban climate features, a 10year-long simulation was conducted for 2001-2010 with the 5.1 version of SURFEX over Budapest. The $1 \mathrm{~km}$ resolution domain consists of $72 \times 72$ gridpoints (Fig. 1). The 10-km horizontal resolution ALADIN was driven by the ERA-Interim re-analysis (Dee et al., 2011), which fields on $30 \mathrm{~m}$ above surface were interpolated to $1 \mathrm{~km}$ horizontal resolution over the SURFEX domain using the EE927 configuration (Fig. 1). This configuration is for horizontal and vertical interpolation of the ALADIN outputs to prepare lateral boundary conditions for a nested model simulation. Its main advantage is that it takes into account the topography as well. These forcings were provided 3 hourly for SURFEX, which linearly interpolates them to its own timestep, i.e., 5 minutes. Land cover information was obtained from the $1 \mathrm{~km}$ resolution ECOCLIMAP-I database (Masson et al., 2003), which combines satellite data, climate maps, and other existing land cover maps and provide parameters for 255 different cover types. Over our domain it distinguishes eight different urban types, amongst them the most important ones are dense urban, temperate suburban, industries and commercial areas, and urban parks. These differ in fraction of urban and nature tiles, canyon parameters (e.g., building height, canyon width, roughness length), vegetation parameters (e.g., leaf area index), etc. Table 1 summarizes the main features of the SURFEX setup and the achieved simulation. 


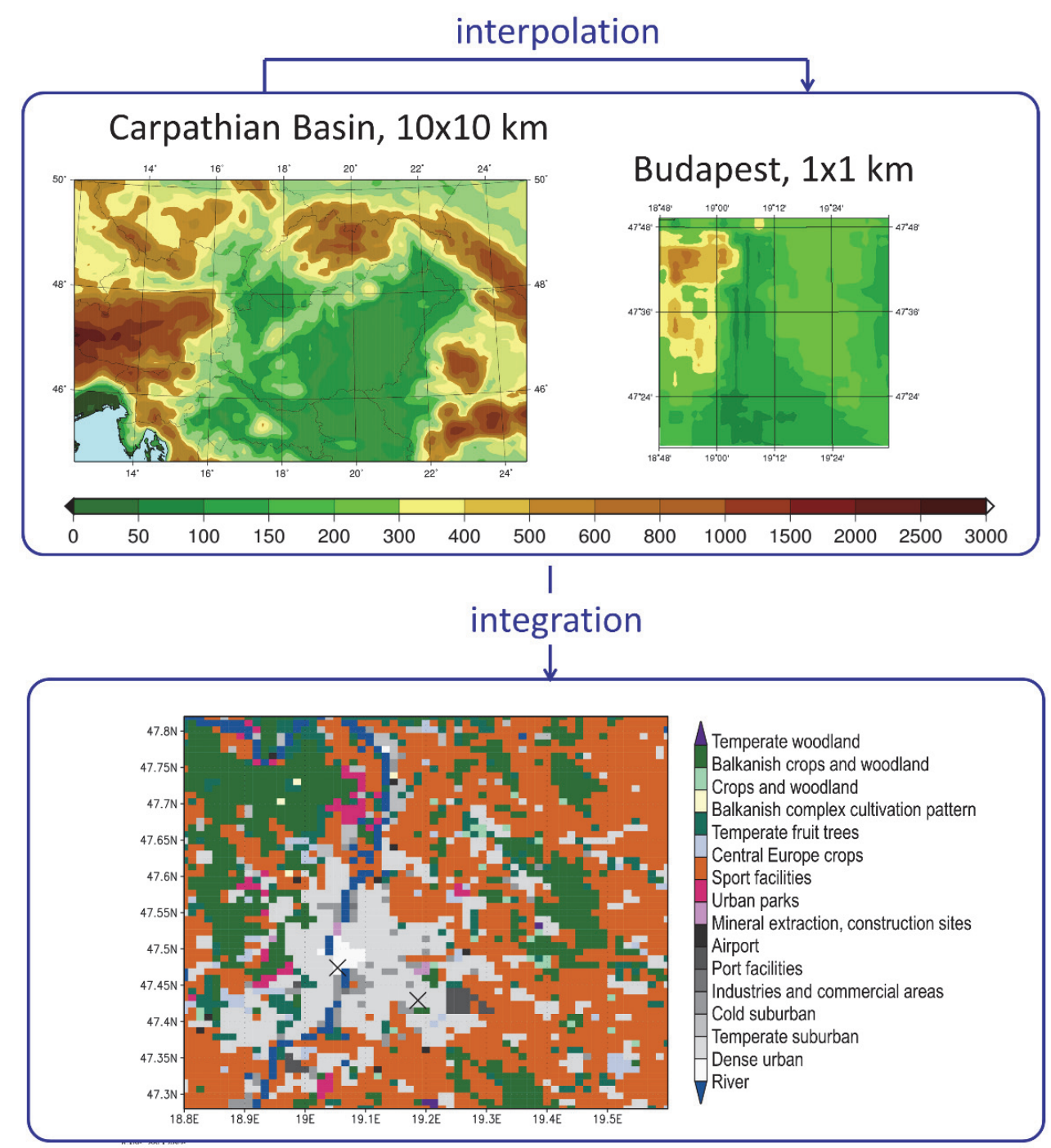

Fig. 1. Flow chart about the use of SURFEX. Top left: domain and topography of the 10 $\mathrm{km}$ resolution ALADIN-Climate; top right: ALADIN model fields interpolated to a $1 \mathrm{~km}$ resolution domain over Budapest. Bottom: land cover type of grid cells according to the ECOCLIMAP database for Budapest. The two validation gridpoints are marked with $\mathrm{x}$.

Table 1. Main parameters of SURFEX setup

\begin{tabular}{|l|l|}
\hline Atmospheric forcings & $\begin{array}{l}\text { 3-hour outputs of ERA-Interim driven } \\
\text { ALADIN-Climate v5.2 }\end{array}$ \\
\hline Height of forcing coupling & $30 \mathrm{~m}$ \\
\hline Resolution & $1 \mathrm{~km}$ \\
\hline Scheme for urban tiles & TEB \\
\hline Scheme for nature tiles & ISBA \\
\hline Land cover & ECOCLIMAP \\
\hline Domain & Budapest \\
\hline Integration period & $2001-2010$ \\
\hline
\end{tabular}


First we briefly validated the $10 \mathrm{~km}$ resolution ALADIN fields against the $10 \mathrm{~km}$ resolution CarpatClim gridded dataset based on observations (Szalai et al., 2013) over the Budapest domain. Then urban climate characteristics simulated by SURFEX were studied investigating the spatial pattern and temporal evolution of $2 \mathrm{~m}$ temperature. In Budapest, the number of operational SYNOP (Surface Synoptic Observations) stations are quite scarce compared to the $1 \mathrm{~km}$ model resolution, hence quantitative validation is possible only in a few gridpoints. Based on location and data availability, $2 \mathrm{~m}$ temperature time series of two stations were used to validate SURFEX (Fig. 2): one in the city center (Lágymányos; $19^{\circ} 3^{\prime} 43^{\prime \prime} \mathrm{E}, 47^{\circ} 28^{\prime} 29^{\prime} \mathrm{N}$ ) and one in the suburban area (Pestszentlórinc; $19^{\circ} 10^{\prime} 56^{\prime \prime} \mathrm{E}, 4^{\circ} 25^{\prime} 45^{\prime \prime} \mathrm{N}$ ). From SURFEX, the corresponding nearest gridpoints were chosen. In ECOCLIMAP, these two gridpoints are associated with dense urban and temperate suburban cover types, respectively (Fig. 1). Table 2 shows their main parameters.
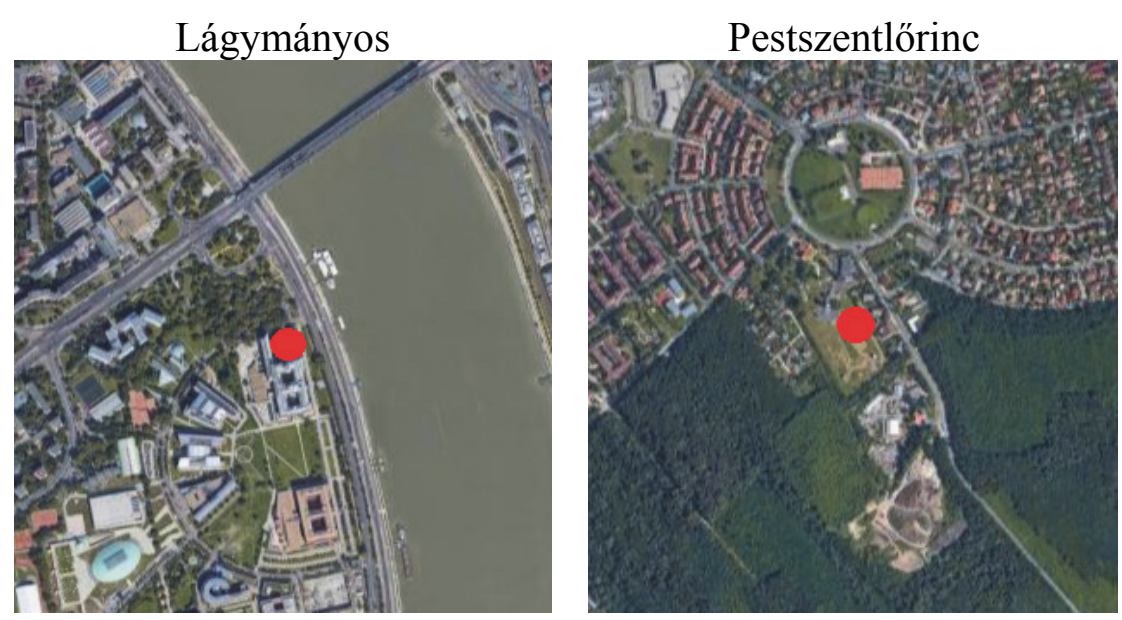

Fig. 2. Two validation points: meteorological stations located in the city center (Lágymányos) and in the southern part of Budapest (Pestszentlőrinc).

Table 2. Urban parameters in the selected gridpoints according to ECOCLIMAP

\begin{tabular}{|l|c|c|}
\hline Land cover type & Dense urban & Temperate suburban \\
\hline Fraction of urban tile & 0.9 & 0.6 \\
\hline Fraction of nature tile & 0.1 & 0.4 \\
\hline Building height & $30 \mathrm{~m}$ & $10 \mathrm{~m}$ \\
\hline Building aspect ratio & 1 & 0.5 \\
\hline Canyon aspect ratio & 1 & 0.5 \\
\hline
\end{tabular}




\section{Results and discussion}

\subsection{Validation of ALADIN-Climate}

The performance of regional climate model providing atmospheric forcings has a great influence on the behavior of the land surface model, therefore, we briefly evaluate the ALADIN near surface fields $(2 \mathrm{~m}$ temperature and relative humidity, $10 \mathrm{~m}$ windspeed and precipitation) over Budapest for 2001-2010. The validation domain consists of 70 grid points data of which were compared to the CarpatClim data. It has to be noted that the spatial and temporal representations of the compared fields differ to some extent. While an ALADIN gridpoint represents the mean value of the corresponding gridbox, CarpatClim consists of pointwise data, although the interpolation technique ensures that they are spatially representative. Daily mean of instantaneous variables (temperature, windspeed, and relative humidity) was computed from 3-hourly ALADIN outputs, while in CarpatClim, only 3-4 data measured in the main standard synoptic hours were considered, except mean temperature, which was derived as the average of daily minimum and maximum temperature values. Nevertheless, we believe that these discrepancies lessen as applying multiyear monthly and seasonal means.

The $2 \mathrm{~m}$ temperature is underestimated with $-1.0-(-1.5){ }^{\circ} \mathrm{C}$ in all seasons except summer, as can be seen on the left panel of Fig. 3, in Fig. 4 and Table 3. However, probably due to the insufficient representation of the hilly area on the northwestern-western part of the domain (i.e., the elevation is lower than in the reality), higher temperatures compared to reference occur in the related gridpoints. The temperature interpolated with ALADIN EE927 (recall that the applied method considers elevation) and aggregated to $10 \mathrm{~km}$ reveal some improvement over these areas (right panel of Fig. 3).

The $2 \mathrm{~m}$ relative humidity is overestimated by ALADIN on average throughout the year, except summer, when the model nearly perfectly simulates the observed values (Fig. 4). However, in this season 37\% more precipitation falls in ALADIN (Table 3), which, together with the positive temperature bias, is a well-known attribute of the model over Hungary (Illy et al., 2015). It may be supposed that the too warm near-surface air layer contains more moisture as well (since relative humidity is unbiased), therefore precipitation overestimation may be related to the enhanced convective activity. Krüzselyi (2013) also found that ALADIN produces too much convective precipitation in summer compared to the ERA-Interim re-analysis. Concurrent to Illy (2017), we also identified too weak near-surface wind speed simulated by ALADIN in every season. 

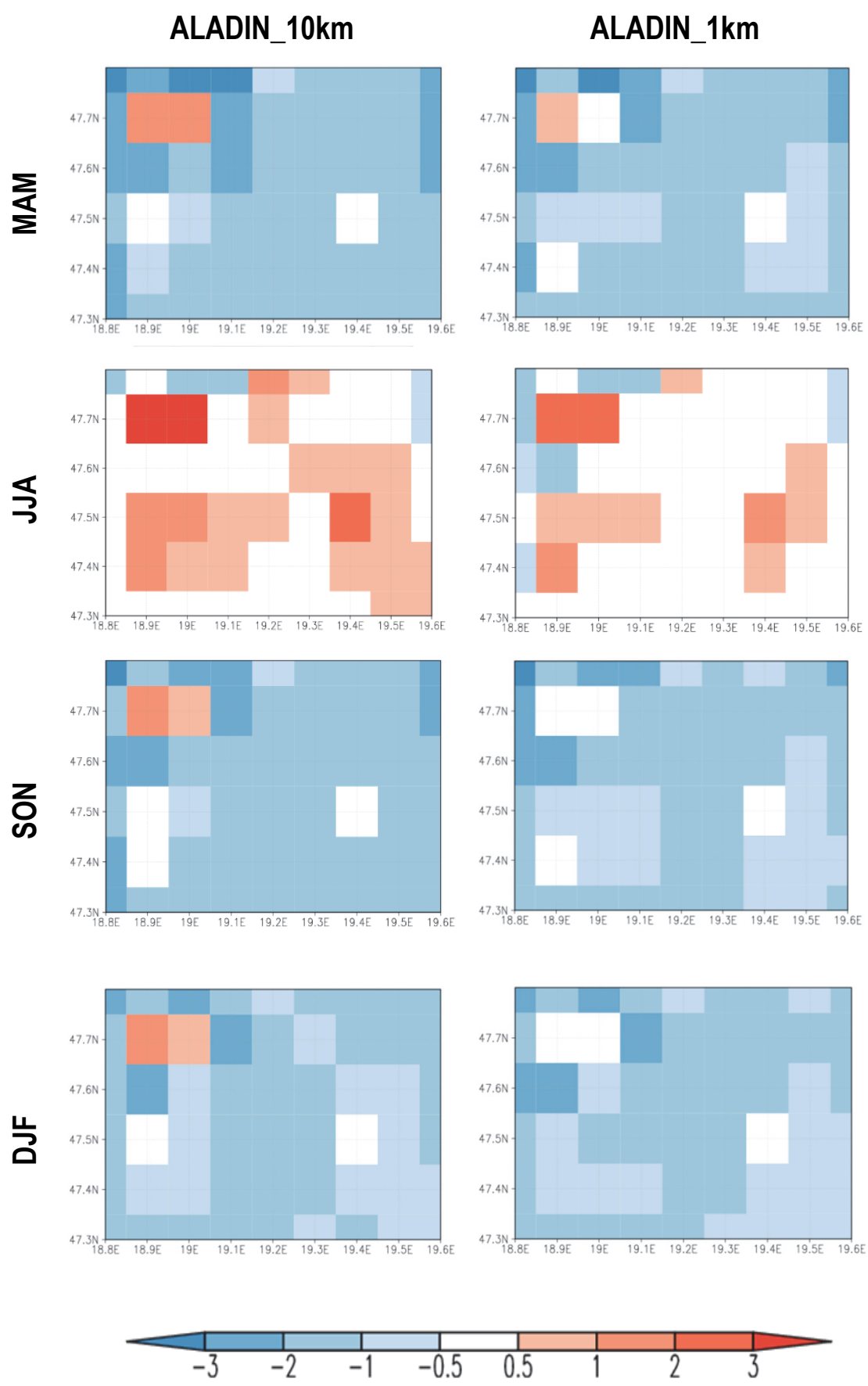

Fig. $3.2 \mathrm{~m}$ temperature bias of the $10 \mathrm{~km}$ resolution ALADIN and $1 \mathrm{~km}$ resolution interpolated field aggregated to $10 \mathrm{~km}$, with reference to CarpatClim for 2001-2010. 

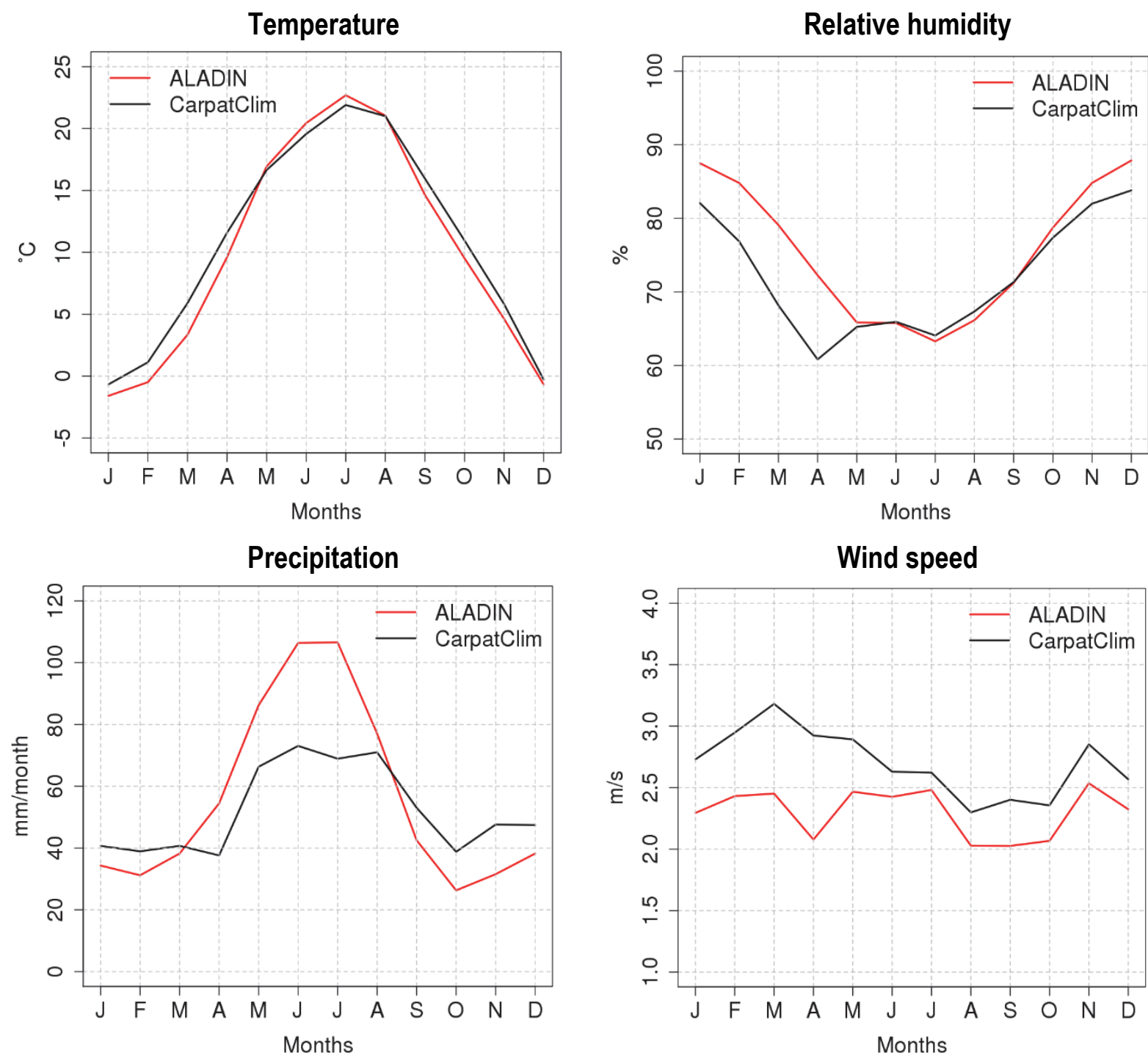

Fig. 4. Area-averaged monthly mean $2 \mathrm{~m}$ temperature (in ${ }^{\circ} \mathrm{C}$ ), relative humidity (in \%), precipitation (in $\mathrm{mm} / \mathrm{month}$ ), and $10 \mathrm{~m}$ wind speed (in $\mathrm{m} / \mathrm{s}$ ) according to ALADIN and CarpatClim for 2001-2010.

Table 3. Seasonal mean area-averaged bias of different variables of ALADIN compared to CarpatClim for 2001-2010

\begin{tabular}{ccccc}
\hline \hline & $\begin{array}{c}\text { Temperature } \\
{\left[{ }^{\circ} \mathbf{C}\right]}\end{array}$ & $\begin{array}{c}\text { Relative humidity } \\
{[\%]}\end{array}$ & $\begin{array}{c}\text { Precipitation } \\
{[\%]}\end{array}$ & $\begin{array}{c}\text { Wind speed } \\
{[\mathbf{m} / \mathbf{s}]}\end{array}$ \\
\hline \hline MAM & -1.5 & 8 & 25 & -0.7 \\
JJA & 0.5 & 0 & 37 & -0.3 \\
SON & -1.4 & 2 & -27 & -0.4 \\
DJF & -1.0 & 6 & -16 & -0.5 \\
\hline
\end{tabular}




\subsection{Validation of SURFEX}

An important feature of TEB is the specific, urban relevant repartitioning of the net radiation into turbulent fluxes. Fig. 5 illustrates the surface energy balance components over the urban and suburban reference points. It can be seen that the available net radiation slightly differ in these two locations, while in the diurnal hours the energy is transported in the form of sensible heat flux rather than latent heat flux in the urban point, thanks to the larger urban land cover fraction. Moreover, more energy is conducted and stored during the day, and slightly more energy is emitted during the night in the urban objects than in the natural surfaces, that leads to the emergence of the nocturnal heat island.

Therefore, due to the detailed representation of surface physical processes and to the fine horizontal resolution, SURFEX simulates mean seasonal $2 \mathrm{~m}$ temperature over Budapest and its vicinity more realistically than ALADIN does (Fig. 6). Urban heat island can be detected in every season and the city center is approximately $2{ }^{\circ} \mathrm{C}$ warmer than the rural areas. Moreover, the detailed orography implemented in SURFEX and the applied interpolated atmospheric forcings result in a realistic spatial distribution of $2 \mathrm{~m}$ temperature outside the city as well, namely the Buda, Pilis, and Visegrád Hills on the northwest-west and the Gödöllö Hills on the east stand out with cooler temperatures, among which the warmer Pest Plain is located.

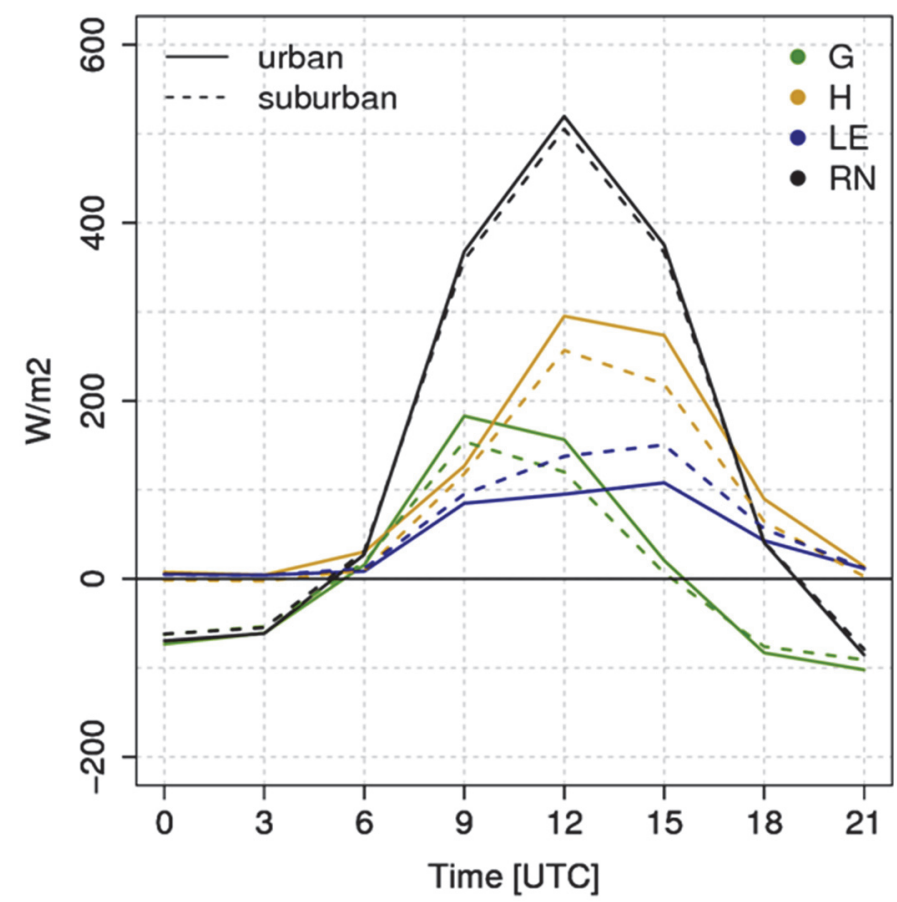

Fig. 5. Summer mean daily cycle of surface energy balance components (G: ground heat flux, H: sensible heat flux, LE: latent heat flux, RN: net radiation) in the urban and suburban reference points in 2001-2010. 

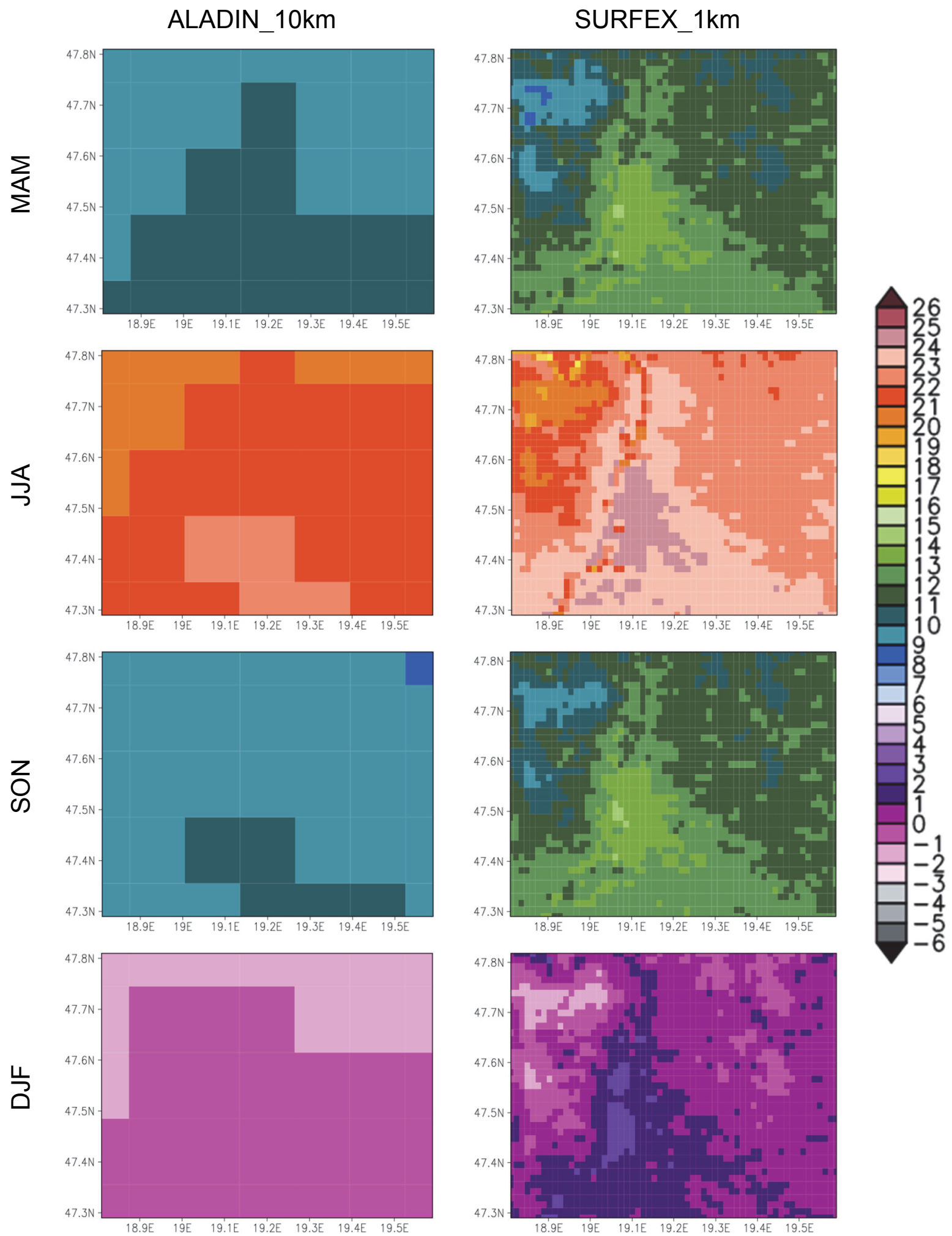

Fig. 6. Seasonal mean $2 \mathrm{~m}$ temperature in the $10 \mathrm{~km}$ resolution ALADIN (left panel) and $1 \mathrm{~km}$ resolution SURFEX (right panel) in 2001-2010. 
It can be said that SURFEX is able to simulate the main characteristics of the climate of Budapest and the surrounding complex orography. To validate the surface model more quantitatively, the annual cycle of $2 \mathrm{~m}$ temperature in the reference urban and suburban gridpoints resulted by SURFEX and interpolated from ALADIN outputs is presented in Fig. 7. As it was already mentioned, ALADIN is too cold in almost every season, except summer, when its bias is significantly reduced. Comparing the two locations, larger underestimation appears in the urban point, that can be explained by the lack of urban representation in ALADIN. As Fig. 6 also suggests, SURFEX adds extra heating to the ALADIN fields resulting in a $0.5-3{ }^{\circ} \mathrm{C}$ overestimation throughout the year, mostly from July to October. This warming is more intense in the urban point (thanks to TEB), therefore, the differences between the bias in the two points reduced. It results in an improved description of the urban heat island, since the systematic bias of SURFEX is eliminated when UHI is derived.

Fig. 7 shows that both minimum and maximum daily temperatures contribute to the mean temperature overestimation. Apart from summer, there is no big difference between the magnitude of daily minimum and maximum overestimation, but in summer, the model has significant shortcomings in simulating nocturnal temperatures.

We also examined the performance of SURFEX describing the diurnal cycle of UHI in each season in the reference points (Fig. 8). From autumn to spring too strong nocturnal urban heat island is simulated, while in summer the daily maximum values do not reach the observed ones. From May to August larger positive bias is found in the suburban point which cause weaker UHI intensity (Fig. 7). This relation between the biases in the two points shift in the rest of the months, which explains the nocturnal UHI overestimation. A delay in the daily UHI cycle can be detected: nocturnal UHI develops slower than observed, and it collapses later as well. A possible explanation behind this deficiency is that we introduce some error, when atmospheric forcings are prepared for SURFEX. Certain variables that are stored cumulatively in ALADIN files (such as radiation and precipitation) in 3-hourly steps are transformed to instantaneous values using linear interpolation. During sunrise and sunset, the linear interpolation method fails to determine correctly the radiation intensities from 3-hourly cumulative values. Therefore, in the morning less energy is provided to the surface that may cause slower warm-up of natural surfaces and longer lasting UHI. In contrast, during sunset larger radiation intensities are produced that delays the development of temperature difference between the urban and rural surfaces. 
Monthly 2 m temperature bias

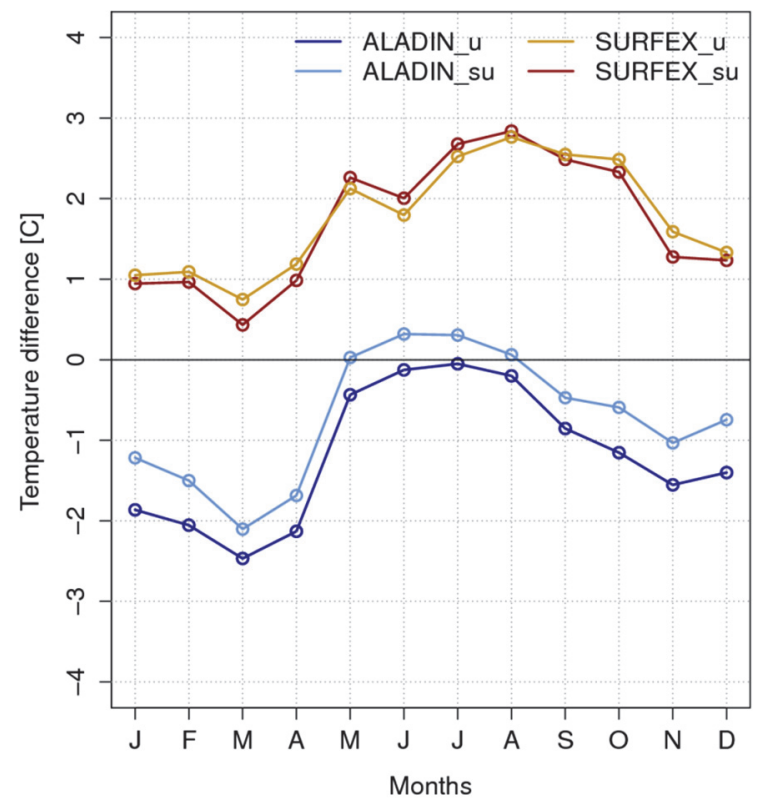

Monthly $2 \mathrm{~m}$ minimum and maximum temperature bias

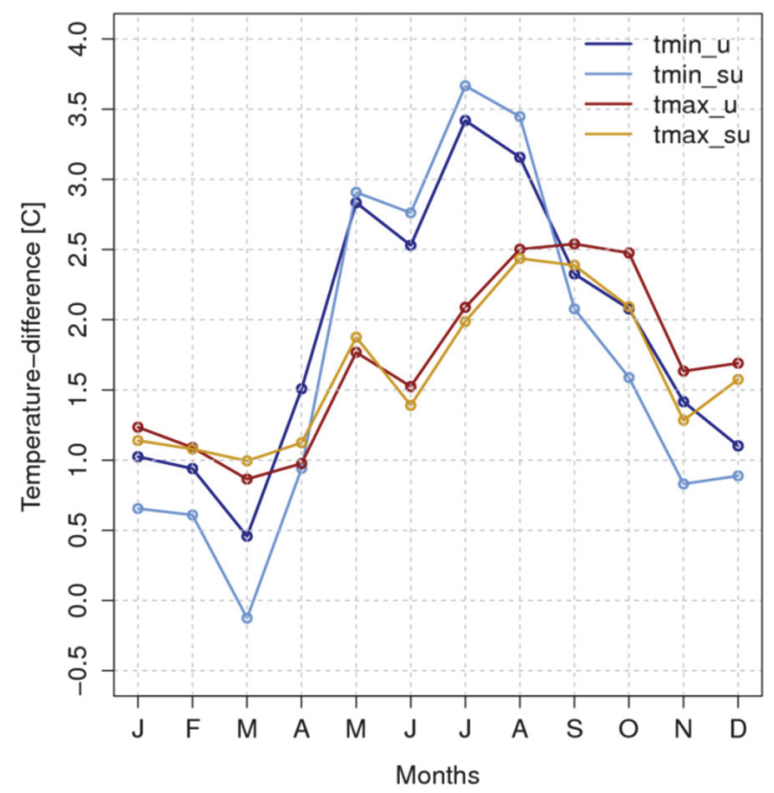

Fig. 7. Monthly $2 \mathrm{~m}$ temperature (left) bias of interpolated ALADIN and SURFEX and minimum and maximum temperature bias (right) of SURFEX in 2001-2010 in the urban (_u) and suburban (_su) reference points with respect to station measurements.

MAM

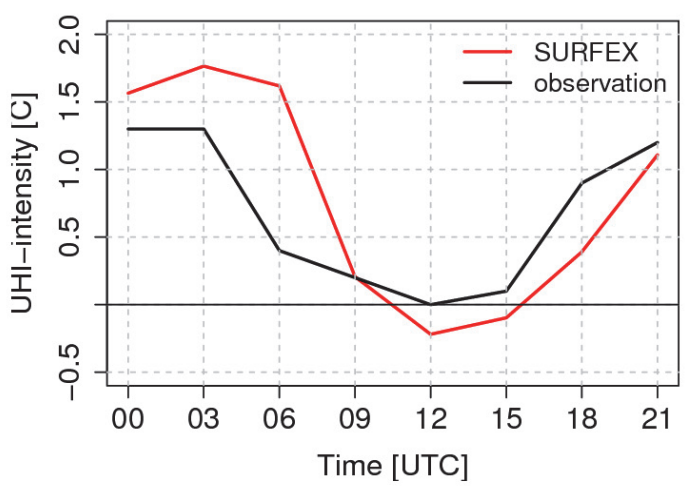

SON

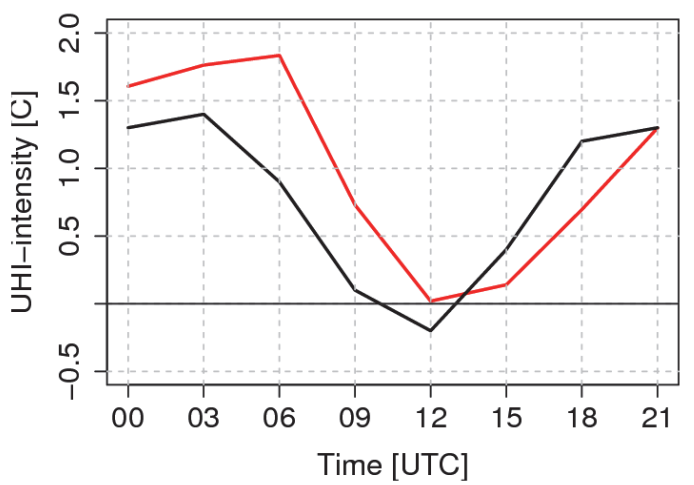

JJA

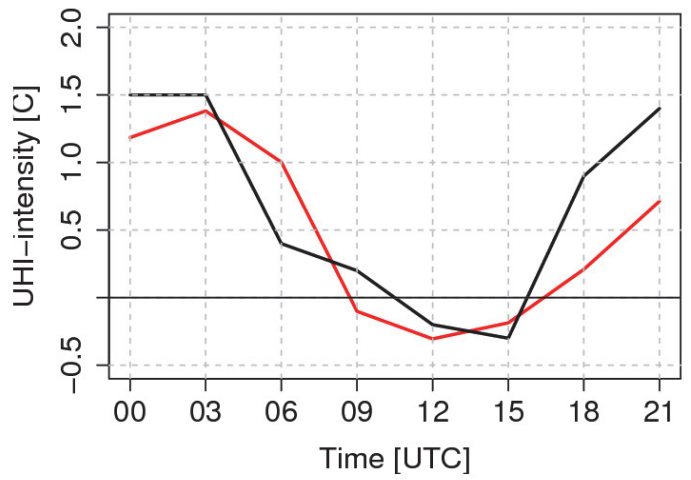

DJF

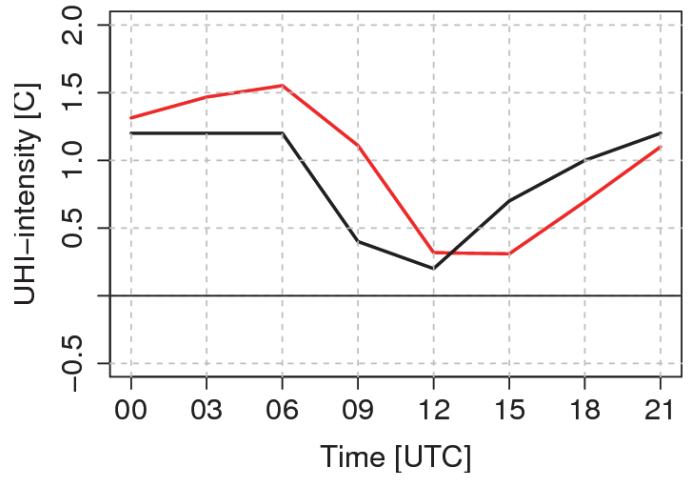

Fig. 8. Daily cycle of UHI in each season according to the SURFEX and station measurements in the reference points for 2001-2010. 


\section{Conclusions}

In this study, the SURFEX surface model was investigated from the aspect of simulating urban climate of Budapest for the period of 2001-2010. The model was coupled in offline mode to the $10 \mathrm{~km}$ resolution ALADIN-Climate with 3-hourly update of atmospheric forcings. On the one hand, added value of the detailed TEB urban parameterization scheme of SURFEX was explored compared to the regional climate model results; on the other hand the simulated temperature and UHI seasonal and daily cycles were validated in an urban and a suburban grid point against station measurements. The main findings are as follows:

- ALADIN underestimates the temperature over Budapest with $(-1.0)-$ $(-1.5){ }^{\circ} \mathrm{C}$ throughout the year except summer, when a slightly positive bias, followed with a strong precipitation overestimation is observed.

- SURFEX warms the ALADIN fields but too heavily, leading to a $0.5-3{ }^{\circ} \mathrm{C}$ seasonally varying positive temperature bias.

- The abovementioned two conclusions coincide with the findings of Vértesi (2011) and Krüzselyi et al. (2016), regardless the investigated time period, gridpoints and the newer re-analysis applied in ALADIN. However, as far as UHI is concerned, a different urban gridpoint selection largely improved the pointwise validation results.

- Nocturnal UHI is overestimated from spring to autumn which can be explained by the larger overestimation in the urban point compared to the suburban one. This relation is veered in summer, therefore nocturnal UHI is weaker as well.

- A delay in the evolution and collapse of UHI is found which may be the outcome of the inadequate linear method of forcing creation.

These results suggest that with a higher forcing frequency update, better daily UHI evolution may be reached. On the other hand, due to the complex orography of Budapest, one cannot purely distinguish the impact of interpolation and the impact of urban scheme on the final results. Therefore, to better understand the behavior of SURFEX, the investigation will be continued over flat terrain, using a more simple spatial interpolation method for deriving atmospheric forcings.

\section{References}

Boone, A., Calvet, J.-C., and Noilhan, J., 1999: Inclusion of a Third Soil Layer in a Land Surface Scheme Using the Force-Restore Method. J. Appl. Meteorol. 38, 1611-1630. https://doi.org/10.1175/1520-0450(1999)038<1611:IOATSL >2.0.CO;2 
Colin, J., Déqué, M., Radu, R., and Somot, S., 2010: Sensitivity study of heavy precipitations in Limited Area Model climate simulation: influence of the size of the domain and the use of the spectral nudging technique. Tellus-A 62, 591-604. https://doi.org/10.1111/j.1600-0870.2010.00467.x

Déqué M., Dreveton C., Braun A., and Cariolle D., 1994: The ARPEGE-IFS atmosphere model: a contribution to the French community climate modelling. Climate Dynam. 10, 249-266. https://doi.org/10.1007/BF00208992

Dee, D.P., Uppala, S.M., Simmons, A.J., Berrisford, P., Poli, P., Kobayashi, S., Andrae, U., Balmaseda, M.A., Balsamo, G., Bauer, P., Bechtold, P., Beljaars, A.C.M., van de Berg, L., Bidlot, J., Bormann, N., Delsol, C., Dragani, R., Fuentes, M., Geer, A.J., Haimberger, L., Healy, S.B., Hersbach, H., Hólm, E.V., Isaksen, L., Kållberg, P., Köhler, M., Matricardi, M., McNally, A.P., Monge-Sanz, B.M., Morcrette, J.-J., Park, B.-K., Peubey, C., de Rosnay, P., Tavolato, C., Thépaut, J.-N., and Vitart, F., 2011: The ERA-Interim reanalysis: configuration and performance of the data assimilation system. Quart. J. Roy. Meteorol. Soc. 137, 553-597. https://doi.org/10.1002/qj.828

Hamdi, R. and Masson, $V$., 2008: Inclusion of a Drag Approach in the Town Energy Balance (TEB) Scheme: Offline 1D Evaluation in a Street Canyon. J. Appl.Meteorol. Climatol. 47, 2627-2644. https://doi.org/10.1175/2008JAMC1865.1

Hamdi, R., Giot, O., De Troch, R., Deckmyn, A., and Termonia, P., 2015: Future climate of Brussels and Paris for the 2050s under the A1B scenario. Urban Climate 12, 160-182. https://doi.org/10.1016/j.uclim.2015.03.003

Illy T., Sábitz J., and Szépszó G., 2015: Validation of the ALADIN-Climate simulation results. Report of the RCMTéR EEA-C13-10 project, Hungarian Meteorological Service, Budapest. 19 p.

Illy, T., 2017: Near-surface wind speed changes in the 21st century based on the results of ALADINClimate regional climate model. Időjárás 121, 161-187.

Krüzselyi, I., 2013: Evaluation of a Euro-CORDEX ALADIN-Climate experiment focusing on Hungary. Paper presented at: General Assembly of the European Geoscience Union. 11 April 2013. Vienna, Austria.

Krüzselyi, I., Zsebeházi, G., and Kovács, M., 2016: Urban Climate Modelling with SURFEX/TEB at the Hungarian Meteorological Service. In (Ed. Musco, F.) Counteracting Urban Heat Island Effects in a Global Climate Change Scenario, pp. 14-21. Springer Nature, Switzerland. https://doi.org/10.1007/978-3-319-10425-6

KSH, 2013: Population cencus 2011. 3. National data. (eds.: Bada, I. Cs., Bulik, L., Dobróka, Z., Gyulai, K., Kerner-Kecskés, B., Simonné H. G., Trybek, K., Weisz, T.) Hungarian Central Statistical Office, Budapest, Hungary. 276p. ISBN 978-963-235-417-0 (in Hungarian)

Le Moigne, P., 2009: SURFEX Scientific Documentation. Note de centre (CNRM/GMME). MétéoFrance, Toulouse, France. 211p.

Lemonsu, A., Viguié, V., Daniel, M., and Masson, V., 2015: Vulnerability to heat waves: Impact of urban expansion scenarios on urban heat island and heat stress in Paris (France). Urban Climate 14, 586-605. https://doi.org/10.1016/j.uclim.2015.10.007

Masson, V., 2000: A Physically-Based Scheme For The Urban Energy Budget In Atmospheric Models. Bound.-Lay. Meteorol. 94, 357-397. https://doi.org/10.1023/A:1002463829265

Masson, V., Champeaux, J.-L., Chauvin, F., Meriguet, C., and Lacaze, R., 2003: A Global Database of Land Surface Parameters at 1-km Resolution in Meteorological and Climate Models. J. Climate 16, 1261-1282. https://doi.org/10.1017/S1350482705001519

Masson V., 2006: Urban surface modeling and the meso-scale impact of cities. Theor. Appl. Climatol. 84, 35-45. https://doi.org/10.1007/s00704-005-0142-3

Masson, V. and Seity, Y., 2009. Including Atmospheric Layers in Vegetation and Urban Offline Surface Schemes. J. Appl. Meteorol. Climatol. 48, 1377-1397. https://doi.org/10.1175/2009JAMC1866.1

McCarthy, M.P., Best, M. J., and Betts, R. A., 2010: Climate change in cities due to global warming and urban effects. Geophys. Res. Lett. 37, L09705. https://doi.org/10.1029/2010GL042845

Noilhan, J. and Mahfouf, J.-F., 1996: The ISBA land surface parameterisation scheme. Glob. Planet. Change 13, 145-159. https://doi.org/10.1016/0921-8181(95)00043-7 
Noilhan, J. and Planton, S., 1989: A Simple Parameterization of Land Surface Processes for Meteorological Models. Mon. Weather Rev. 117, 536-549. https://doi.org/10.1175/1520-0493(1989)117<0536:ASPOLS >2.0.CO;2

Oke, T.R., 1987: Boundary Layer Climates. $2^{\text {nd }}$ edition. Methuen Publishers, London, United Kingdom. 435p. ISBN 0-415-04319-0

Resler, J., Krč, P., Belda, M., Juruš, P., Benešová, N., Lopata, J., Vlček, O., Damašková, D., Eben, K., Derbek, P., Maronga, B., and Kanani-Sühring, F., 2017: PALM-USM v1.0: A new urban surface model integrated into the PALM large-eddy simulation model. Geosci. Model Dev. 10, 3635-3659. https://doi.org/10.5194/gmd-10-3635-2017

Szalai, S., Auer, I., Hiebl, J., Milkovich, J., Radim, T. Stepanek, P., Zahradnicek, P., Bihari, Z., Lakatos, M., Szentimrey, T., Limanowka, D., Kilar, P., Cheval, S., Deak, Gy., Mihic, D., Antolovic, I., Mihajlovic, V., Nejedlik, P., Stastny, P., Mikulova, K., Nabyvanets, I., Skyryk, O., Krakovskaya, S.,Vogt, J., Antofie, T., and Spinoni, J. 2013: Climate of the Greater Carpathian Region. Final Technical Report.

Termonia, P., Fischer, C., Bazile, E., Bouyssel, F., Brožková, R., Bénard, P., Bochenek, B., Degrauwe, D., Derková, M., El Khatib, R., Hamdi, R., Mašek, J., Pottier, P., Pristov, N., Seity, Y., Smoliková, P., Španiel, O., Tudor, M., Wang, Y., Wittmann, C., and Joly, A., 2018: The ALADIN System and its canonical model configurations AROME CY41T1 and ALARO CY40T1. Geosci. Model Dev. 11, 257-281. https://doi.org/10.5194/gmd-11-257-2018

UN, 2014: Concise Report on the World Population Situation in 2014. Department of Economic and Social Affairs, United Nations, New York, USA. 38p. ISBN 978-92-1-151518-3

Vértesi, Á. É., 2011: Modelling possibilities of the urban heat island effect in Budapest Master Thesis. ELTE, Budapest, Hungary. 78p. (in Hungarian)

Wilby, R., 2003: Past and projected trends in London's Urban heat island. Weather 58, 251-260. https://doi.org/10.1256/wea.183.02 